\title{
Energy Potential of Natural, Synthetic Polymers and Waste Materials - A Review
}

\author{
Michael Ioelovich* \\ Celdezygner Ltd, Rehovot, Israel
}

Submission: May 05, 2018; Published: May 25, 2018

*Corresponding author: Michael Ioelovich, 2 Bergman St., Rehovot, Israel, Tel: 972-89366612; Fax: 972-89366614; Email: ioelovichm@gmail.com

\begin{abstract}
In this paper, the energy potential of natural (polysaccharides, lignin, etc.), and synthetic polymers (polyolefins, etc.), polymer materials (plant biomass, plastics and their solid waste), as well as combustible liquids and gases derived from them has been studied. To determine calorific values of solid, liquid and gaseous substances, various experimental and calculation methods were used. For this purpose, improved equations based on chemical structure and elemental analysis was proposed. It was shown that the conversion of solid materials into liquids or gases reduces the yield of thermal energy. Therefore for the production of thermal energy, it is more profitable to burn the solid biomass or plastic than combustible liquids and gases, derived from them. Studies have shown that lipids and lignin increase, whereas moisture and ash reduce the calorific value of biomass. The calorific value of most synthetic polymers and plastics is higher than that of biomass samples, but resources of waste plastics are about 10 times lower than these of biomass. The use of compacted mixture of biomass and plastic waste enables to obtain solid fuels with unique properties, such as increased calorific value and energy density, as well as reduced emission of carbon dioxide. Considering the total amount of biomass and plastics waste destined for combustion, it was calculated that current annual energy potential of the waste materials is about $145 \mathrm{EJ}$. The increase the share of biomass in the production of alternative energy can simultaneously contribute to reducing in greenhouse gas emission and improving the ecological state of the environment.
\end{abstract}

Keywords: Plant polymers; Biomass; Synthetic polymers; Plastics; Solid waste; Solid fuel; Liquid fuel; Gaseous fuel; Calorific value; Energy density; Energetic potential

\section{Introduction}

The supply of sustainable energy is the basis of modern civilization. Nowadays, the main energy sources are fossil fuels, coal, petroleum and natural gas, which cover up to $80 \%$ of global energy consumption [1]. However, the use of fossil fuels causes the emission of large volumes of greenhouse gas - carbon dioxide, in the amount of $1600-1800 \mathrm{~m}^{3}$ per ton of fuel. The further intensive energy consumption can leads to irrevocable depletion of reserves of these fuels. Therefore in recent years a considerable attention has been paid to plant biomass as inexpensive and inexhaustible source of renewable energy [2].

The term "biomass" means here a variety of plant materials, as well as their residues and wastes [3]. Total resources of such biomass reach 1.5 trillion tons and increase by 200-250 billion tons annually as a result of the photo- and biosynthesis [4]. The main structural constituents of plant biomass are three natural polymers, and namely cellulose, hemicelluloses, and lignin. Being the most abundant organic matter on Earth, cellulose forms the skeleton of cell walls of various plants. The content of cellulose in herbaceous plants is 30 to $40 \%$, in woods 45 to $50 \%$, in best plants (flax, ramie, jute, etc.) 60 to $70 \%$, and in cotton fibers upwards of $90 \%[5]$.
Cellulose is a natural semi crystalline polysaccharide having long linear chains consisting of repeat anhydroglucose units in a "chair" conformation [6]. The linear macromolecules joined by hydrogen bonds form super molecular structure of cellulose that consists of thread-like elementary nanofibrils and their bundles called micro fibrils. Within the elementary fibrils, ordered crystallites and disordered non-crystalline domains (DD) are present. During the process of isolation and modification of cellulose, the cleavage of glycosidic bonds in DD occurs, which leads to partial depolymerization of this polysaccharide. Hemicelluloses are non-cellulose polysaccharides comprising of pentosans and hexosans [1]. The content of these components in various plants is 20 to $40 \%$. Hemicelluloses are hydrophilic amorphous heteropolymers. The chemical structure of hemicelluloses consists of chains of a variety of acetylated links of pentoses or hexoses and backbones [7]. In the plant cells, hemicelluloses are binders between fibrils of cellulose and lignin.

Lignin is a rigid, aromatic, amorphous and hydrophobic polymer that is stable to some chemical reagents and cellulolytic enzymes [7]. The content of lignin in plant biomass ranges from $10 \%$ for corn cob or rice straw to $48 \%$ for olive husk $[8,9]$. Lignin is 
a complex polymer of phenylpropane units, which are cross-linked to each other with a variety of different chemical bonds [10]. In the lignified plant biomass, one portion of lignin is localized between the cells, while another portion of lignin is localized inside the cell wall in the form of thin hydrophobic nano-layers. The cellulose nanofibrils inside the plant cell wall are separated from each other by means of the thin layers of amorphous hemicelluloses, whereas fibrillar bundles consisting of the nanofibrils of cellulose and hemicelluloses are surrounded with hydrophobic nano-layers of lignin, which protect the hydrophilic polysaccharides against biological and chemical attack [11].

Polymeric constituents of biomass are formed in nature by photosynthesis absorbing the solar energy. At first, monomeric sugars are synthesized in chlorophyll pigment of plant leaves from carbon dioxide and water absorbing quanta of red and blue-violet light $[12,13]$. Photosynthesis is a complex, multistage process that is proceeding in two phases - light and the dark. The light phase occurs in the presence of light in the thylakoid membranes of chlorophyll, with the participation of electron transfer proteins, specific carrier NADP and ATP-synthase, the result of which is photolysis of water molecules, binding of formed hydrogen by NADP and release of oxygen. The dark phase proceeds without light with use of NADP $\bullet H_{2}$ complex and carbon dioxide and their transformation to monomeric sugar with the participation of ATP. Summary process of photosynthesis of monomeric $C_{5}$ - and $C_{6}$ -sugars can be described as follows:

$$
\begin{aligned}
& 5 \mathrm{CO}_{2}+5 \mathrm{H}_{2} \mathrm{O}+\text { light } \rightarrow \mathrm{C}_{5} \mathrm{H}_{10} \mathrm{O}_{5}+5 \mathrm{O}_{2} \\
& 6 \mathrm{CO}_{2}+6 \mathrm{H}_{2} \mathrm{O}+\text { light } \rightarrow \mathrm{C}_{6} \mathrm{H}_{12} \mathrm{O}_{6}+6 \mathrm{O}_{2}
\end{aligned}
$$

At biosynthesis of cellulose and starch, glucose is used as $\mathrm{C}_{6}$-monomer in polycondensation reaction with formation of long polymeric chains. Cellulose of plants is formed on the surface of plasma membranes of living cells using a terminal enzymatic complex shaped as a nano-rosette with a hole in the middle [14,15]. At biosynthesis of hemicelluloses, hexosans and pentosans, photo-synthesized hexoses (e.g. mannose) and pentoses (e.g. xylose) participate in polycondensation reactions. The photo-synthesized sugars are probably the precursors of lignin biosynthesis in the plant cell walls $[16,17]$. In the process of biochemical reactions these sugars form a series of aromatic acids, aldehydes and alcohols, which are then polymerized into lignin.

In fact, biomass can be considered an accumulator of solar energy captured during photosynthesis. To generate the heat energy the plant biomass is burned, resulting in the release of accumulated solar energy. Various biomasses and plant-based materials can be used as solid fuels such as wood (e.g. firewood, pellets), herbaceous plants (e.g. Miscanthus, Switch grass, Bermuda grass, etc.), forest residues (e.g. sawdust, twigs, shrubs, etc.), residues of agricultural plants (e.g. stalks, husks, cobs, etc.), residues and wastes of textile, pulp, paper and cardboard, as well as algae biomass. Energy is also obtained by burning of refuse, containing waste paper, cardboard, textile, wood and other plant waste. In many countries, these bio-resources account for over $90 \%$ of household energy consumption [18].

A specific feature of plant biomass is that this solid biofuel is neutral for emission of carbon dioxide, since its burning produces the same amount of this green house gas as it was absorbed from the atmosphere during biosynthesis. Furthermore, the biomass can be used also as feedstock for production of liquid and gaseous biofuels. Currently, plant biomass is the fourth largest energy source after fossil fuels [19]. Moreover, it is the largest source of renewable and alternative energy sources, far ahead of solar, wind and nuclear power stations, as well as hydroelectric and some other power stations $[20,21]$.

An additional energy source can be waste of synthetic polymers and plastics. At present, polymeric materials are widely used for the production of packaging materials, consumer goods and diverse industrial products. Every year in the world about 250-300 million tons of plastics are produced [22]. However after usage, these biostable polymer products are thrown away and pollute the environment. A huge problem is also the pollution of water bodies and oceans with polymer debris [23]. The cardinal way of eliminating biostable plastic debris is burning, which allows also generating an additional thermal energy.

Thereby, the main purpose of this review was to evaluate the energy potential of natural and synthetic polymers and materials such as plant biomass, plastics and their solid waste, as well as combustible liquids and gases derived from them, in order to use them in energy production.

\section{Thermochemistry of Fuels}

The specific heat energy or calorific value of solid fuels or organic matters can beexpressed by higher heating value (HHV) and lower heating value (LHV) also called net combustion heat (NCH). The HHV has the same meaning as the enthalpy of combustion, which assumes a return of temperature to the standard value; in this case the water vapor produced by combustion is condensed to a liquid, hence yielding its condensation heat [24-26]. As opposed to HHV, the LHV or NCH assumes that water remains in vapor state at the end of combustion process [27-29]. Thus, the LHV or $\mathrm{NCH}$ characterizes the actual combustion process. The following notations were used to simplify the symbols: HHV=Q and LHV $(\mathrm{NCH})=\mathrm{q}$. These characteristics of calorific value are connected to each other by the relationship [30]:

$$
q(M J / k g)=Q(M J / k g)-0.22 H
$$

Where,

$\mathrm{H}$ is percentage of hydrogen in a sample

To study the calorific value of solid fuels or organic matters various methods can be used. The first is experimental determination of HHV, which is performed by combustion of 
organic sample in a special device, bomb calorimeter [31-34]. The calorimetric experiment can be briefly described, as follows. The small sample $(1 \mathrm{~g})$ is put into special container of calorimetric bomb, which is filled with moist oxygen under increased pressure. The bomb is closed and put into isothermal water calorimeter. The system is thermo stated at $298.15 \mathrm{~K}$ to achieve an equilibrium state. After ignition of the sample, the temperature rise $(\Delta \mathrm{T})$ is measured. The higher heat of combustion is calculated from equation:

$$
Q=\left[C \Delta T-\left(e_{1}+e_{2}\right)\right] / m
$$

where $\mathrm{m}$ is mass of the dry sample , $\mathrm{C}$ is value of energy equivalent of the bomb calorimeter determined by burning of standard benzoic acid; $e_{1}$ and $e_{2}$ is correction for ignition energy and possible formation and dissolutions of acids (sulphuric or/and nitric) from trace $\mathrm{S}$ or/and $\mathrm{N}$ elements of the sample, respectively.

However, the bomb calorimeter is a complex, expensive and not always available device. In addition, the measurement of calorific value is lengthy and requires multiple repetitions to obtain a reliable result.

Other method is based on Hess's law, according to which the combustion enthalpy at standard conditions can be calculated from difference between formation enthalpies of combustion products $\left(\Delta_{f} H_{p i}\right)$ and formation enthalpy of the combustible matter $\left(\Delta_{f} H_{o}\right)$ :

$$
\Delta_{c} H=\Sigma n_{i} \Delta_{f} H_{p, i}-\Delta_{f} H_{O}
$$

Wherein is number of moles of various products of combustion, i.e. $\mathrm{CO}_{2}, \mathrm{H}_{2} \mathrm{O}, \mathrm{SO}_{2}$, etc

Consider, for example, burning process of cellulose:

$$
\mathrm{C}_{6} \mathrm{H}_{10} \mathrm{O}_{6}+6 \mathrm{O}_{2} \rightarrow 6 \mathrm{CO}_{2}+5 \mathrm{H}_{2} \mathrm{O}
$$

It can be found from thermodynamic handbook that $\Delta_{f} \mathrm{H}_{p}, \mathrm{co}_{2}=-393.51 \mathrm{KJ} / \mathrm{mol}$, $\Delta_{f} H_{p},_{H_{2} O}=-285.83 \mathrm{KJ} / \mathrm{mol}$ and $\Delta_{f} H_{O 2}=0$. Standard formation enthalpy of cellulose is, on average: $\Delta_{f} H_{o}=-965 \mathrm{KJ} / \mathrm{mol} \quad[34,35]$. Then, the combustion enthalpy of cellulose can be calculated by eq. (2): $\Delta_{c} H=-(6 \times 393.51)-(5 \times-285.83)-965=-2825(\mathrm{KJ} / \mathrm{mol})$ . Thus, HHV of cellulose sample: $Q \approx-\Delta_{c} H=2825 \mathrm{KJ} / \mathrm{mol} 17.4 \mathrm{MJ} / \mathrm{kg}$, and $q=16.1 \mathrm{MJ} / \mathrm{KG}$.

Third method is based on the combustion process of organic matter:

$\mathrm{C}_{c} \mathrm{H}_{h} \mathrm{O}_{o} \mathrm{~S}_{s} \mathrm{~N}_{n}+\mathrm{K}_{\mathrm{O} 2} \mathrm{O}_{2} \rightarrow c \mathrm{CO}_{2}+(h / 2) \mathrm{H}_{2} \mathrm{O}+s \mathrm{SO}_{2}+(n / 2) \mathrm{N}_{2}$

Where $K_{\mathrm{O}_{2}}$ is consumption of oxygen (moles per $1 \mathrm{~mol}$ of the matter); c, h, o, s, $\mathrm{n}$ is number of the corresponding atoms in molecule of low-molecular substance or in repeating unit of polymer.

As it is follows from the combustion reaction,

$K_{O 2}=c+0.25 h+s-0.5 o$

According to hypothesis proposed in [36,37], a net combustion heat $(\mathrm{NCH})$ of organic matter is directly proportional to oxygen consumption, i.e.:

$$
q_{c}=E K_{O 2} M^{-1}
$$

Or

$$
q_{c}=E M^{-1}(c+0.25 h+s-0.5 o)
$$

Where $E \approx 418 \mathrm{KJ} /$ mole $\mathrm{O}_{2}$ is energetic parameter; $\mathrm{M}$ is molecular weight of low-molecular substance or repeating unit of polymer.

By finding the $K_{\mathrm{O}_{2}}$ value or number of the atoms c, h, o and s from combustion reaction, it can easily to calculate the net heating

\begin{tabular}{|c|c|c|c|c|c|c|c|}
\hline Sample & Formula & M & $\mathbf{K}_{\mathbf{0 2}}$ & $\mathbf{K}^{\circ}{ }_{02}$ & $\mathrm{q}_{\mathrm{c}}, \mathrm{MJ} / \mathrm{kg}$ & $\mathbf{q}_{\mathrm{c}, \mathrm{o}^{\prime}}, \mathrm{MJ} / \mathrm{kg}$ & $q_{e^{\prime}}, M J / k g$ \\
\hline Methane & $\mathrm{CH}_{4}$ & 16 & 2 & 1.96 & 52.2 & 50.6 & 50.0 \\
\hline Ethane & $\mathrm{C}_{2} \mathrm{H}_{6}$ & 30 & 3.5 & 3.44 & 48.8 & 27.4 & 47.6 \\
\hline Propane & $\mathrm{C}_{3} \mathrm{H}_{8}$ & 44 & 5 & 4.92 & 47.5 & 46.2 & 46.4 \\
\hline Butane & $\mathrm{C}_{4} \mathrm{H}_{10}$ & 58 & 6.5 & 6.4 & 46.8 & 45.6 & 45.8 \\
\hline Hexane & $\mathrm{C}_{6} \mathrm{H}_{14}$ & 86 & 9.5 & 9.36 & 46.2 & 44.9 & 44.8 \\
\hline Heptane & $\mathrm{C}_{7} \mathrm{H}_{16}$ & 100 & 11 & 10.84 & 45.9 & 44.8 & 44.7 \\
\hline Isooctane & $\mathrm{C}_{8} \mathrm{H}_{18}$ & 114 & 12.5 & 12.32 & 45.8 & 44.6 & 44.5 \\
\hline Benzene & $\mathrm{C}_{6} \mathrm{H}_{6}$ & 78 & 7.5 & 7.44 & 40.2 & 39.4 & 40.0 \\
\hline Toluene & $\mathrm{C}_{7} \mathrm{H}_{8}$ & 92 & 9 & 8.92 & 40.9 & 40.0 & 40.5 \\
\hline Methanol & $\mathrm{CH}_{4} \mathrm{O}$ & 32 & 1.5 & 1.54 & 19.6 & 19.8 & 20.0 \\
\hline
\end{tabular}
value of organic matter by eq. (4) or (5).The results showed that the calculated values differ from experimental values of $\mathrm{NCH}$ within $\pm 6 \%$. (Table 1 \& 2 )

Table 1: Comparison of calculated $\left(q_{c} ; q_{c}, 0\right)$ and experimental $\left(q_{e}\right)$ values of net combustion heat for some low-molecular substances. 


\begin{tabular}{|c|c|c|c|c|c|c|c|}
\hline Ethanol & $\mathrm{C}_{2} \mathrm{H}_{6} \mathrm{O}$ & 46 & 3 & 3.02 & 27.3 & 27.0 & 27.1 \\
\hline Propanol & $\mathrm{C}_{3} \mathrm{H}_{8} \mathrm{O}$ & 60 & 4.5 & 4.5 & 31.3 & 30.9 & 31.0 \\
\hline Butanol & $\mathrm{C}_{4} \mathrm{H}_{10} \mathrm{O}$ & 74 & 6 & 5.98 & 33.9 & 33.3 & 34.0 \\
\hline Stearin & $\mathrm{C}_{18} \mathrm{H}_{36} \mathrm{O}_{2}$ & 284 & 26 & 25.8 & 38.2 & 37.5 & 37.5 \\
\hline Abietic acid & $\mathrm{C}_{20} \mathrm{H}_{30} \mathrm{O}_{2}$ & 302 & 26.5 & 26.36 & 36.7 & 36.0 & 36.1 \\
\hline Wax & $\mathrm{C}_{36} \mathrm{H}_{70} \mathrm{O}_{5}$ & 582 & 51 & 50.7 & 36.6 & 35.9 & 36.2 \\
\hline Paraffin & $\mathrm{C}_{31} \mathrm{H}_{64}$ & 436 & 47 & 46.36 & 45.0 & 43.9 & 44.0 \\
\hline
\end{tabular}

Table 2: Comparison of calculated $\left(\mathrm{q}_{\mathrm{c}} ; \mathrm{q}_{\mathrm{c}}, 0\right)$ and experimental $\left(\mathrm{q}_{\mathrm{e}}\right)$ values of net combustion heat for some synthetic and natural polymers.

\begin{tabular}{|c|c|c|c|c|c|c|c|}
\hline Sample & Repeating Unit & $\mathbf{M}$ & KO2 & КоO2 & $q c, M J / k g$ & $q \mathrm{c}, \mathrm{o}, \mathrm{MJ} / \mathrm{kg}$ & qe, $M J / k g$ \\
\hline $\mathrm{PE}$ & $-\mathrm{CH}_{2}^{-}$ & 14 & 1.5 & 1.48 & 44.8 & 43.7 & 44.6 \\
\hline PP & $-\mathrm{C}_{3} \mathrm{H}_{6}^{-}$ & 42 & 4.5 & 4.44 & 44.8 & 43.7 & 44.6 \\
\hline Rubber & $-\mathrm{C}_{5} \mathrm{H}_{8}^{-}$ & 68 & 7 & 6.92 & 43.0 & 42.0 & 42.4 \\
\hline PMMA & $-\mathrm{C}_{5} \mathrm{H}_{8} \mathrm{O}_{2}^{-}$ & 100 & 6 & 6.08 & 25.1 & 25.1 & 25.0 \\
\hline PS & -C8H8- & 104 & 10 & 9.92 & 40.2 & 39.4 & 40.0 \\
\hline PA-6 & $-\mathrm{C}_{6} \mathrm{H}_{11} \mathrm{ON}-$ & 113 & 8.25 & 8.22 & 30.5 & 30.0 & 30.2 \\
\hline PET & $-\mathrm{C}_{10} \mathrm{H}_{8} \mathrm{O}_{4^{-}}$ & 192 & 10 & 10.24 & 21.8 & 22.0 & 23.2 \\
\hline Xylan & $-\mathrm{C}_{5} \mathrm{H}_{8} \mathrm{O}_{4}^{-}$ & 132 & 5 & 5.24 & 15.8 & 16.4 & 16.5 \\
\hline Mannan & $-\mathrm{C}_{6} \mathrm{H}_{10} \mathrm{O}_{5}-$ & 162 & 6 & 6.3 & 15.5 & 16.1 & 16.1 \\
\hline Cellulose & $-\mathrm{C}_{6} \mathrm{H}_{10} \mathrm{O}_{5}-$ & 162 & 6 & 6.3 & 15.5 & 16.1 & 16.1 \\
\hline Lignin & $-\mathrm{C}_{10} \mathrm{H}_{11} \mathrm{O}_{3.5}$ & 187 & 11 & 11.17 & 24.5 & 24.7 & 24.8 \\
\hline
\end{tabular}

In the case when it is necessary to find the HHV, the following equation can be used:

$$
Q=q+22 h M^{-1}
$$

To reduce the divergence between the calculated and experimental values, several corrections were introduced in eq. (4), (5) and (6). As a result, the following improved equations were derived [38]:

$$
\begin{aligned}
& K^{\circ}{ }_{O 2}=c+0.24 h+0.81 s-0.42 o \\
& q_{c, o}=E_{\circ} K^{\circ}{ }_{O 2} M^{-1} \\
& \text { Or } q_{c, o}=E_{\circ} M^{-1}(c+0.24 h+0.81 s-0.42 o)
\end{aligned}
$$

Where $E_{\circ}=413 \mathrm{~kJ} /$ mole $O_{2}$ is corrected energetic parameter;
$K^{\circ}{ }_{O 2}$ is corrected parameter of oxygen consumption.

The improved equations permit to reduce the discrepancy between calculated and experimental values to $\pm 1 \%$ (Table 1 \& 2).

In addition, it is necessary to mention a few correlation methods. One from them is based on the contribution of structural groups to the HHV [36] (Table 3). HHV of the sample was calculated by the equation:

$$
Q=\left(\Sigma n_{i} Q_{i}\right) M^{-1}
$$

Then, the NCH of the sample can be calculated from eq. (1) or (12).

Table 3: Structural groups and their contribution to the HHV [36].

\begin{tabular}{|c|c|c|c|}
\hline Group & $\mathbf{Q}_{\mathbf{i}}, \mathbf{k J} / \mathbf{m o l}$ Group & Group & $\mathbf{Q}_{\mathbf{i}}, \mathbf{k J} / \mathbf{m o l}$ Group \\
\hline$-\mathrm{CH}_{3}$ & 775 & $-\mathrm{COO}-$ & 112 \\
\hline$-\mathrm{CH}_{2}-$ & 670 & $-\mathrm{C}=0$ & 259 \\
\hline$-\mathrm{CH}-$ & 518 & $-\mathrm{NH}-$ & 77 \\
\hline$-\mathrm{C}-$ & 431 & $-0-$ & -132 \\
\hline$-\mathrm{H}$ & 190 & $-\mathrm{OH}$ & -108 \\
\hline
\end{tabular}




$$
q=Q-22 h M^{-1}
$$

The verification showed that the method of contribution of structural groups makes it possible to predict the heating value of various organic substances and polymers with accuracy of $\pm 5 \%$.

Other correlation methods are based on the determination of percentage of $\mathrm{C}, \mathrm{H}, \mathrm{O}, \mathrm{S}$ and $\mathrm{N}$ atoms in molecule of low-molecular substance or in repeating unit of polymer:

$$
q(M J / K g)=a C+b H+c S-(d O+e N)
$$

Where a, b, c, d, e - coefficients; C, H, O, S and N are percentage of corresponds atoms calculating from formula of the organic substance.

In the known equation of Mendeleev [39,40] a = 0.339, b=1.035, $c=0.109, d=0.109$ and $e=0.015$. Parikh et al. [41] proposed other coefficients of eq. (12): $a=0.349, b=0.960, c=0.101, d=0.103$ and $\mathrm{e}=0.015$. Study have shown that the equation of Mendeleev gives depressed values $(-5 \%)$, whereas the equation of Parikh gives overestimated results $(+5 \%)$ in comparison with experimental values of NCH. To increase the accuracy of calculations the corrected coefficients were proposed [42]: $a=0.344, b=1.000$, $c=0.105, \mathrm{~d}=0.106$ and $\mathrm{e}=0.015$.

$$
q(M J / k g)=0.344 C+H+0.105 S-(0.106 O+0.015 N)(14)
$$

As a result, the difference between calculated and experimental values can be reduced to $\pm 1 \%$ (Table 4 ).

Table 4: Comparison of calculated $\left(q_{c}\right)$ and experimental $\left(q_{e}\right)$ values of net combustion heat for some organic substances and polymers.

\begin{tabular}{|c|c|c|}
\hline Sample & $\mathbf{q}_{\mathbf{c}}, \mathbf{M J} / \mathbf{k g}$ & $\mathbf{q}_{\mathrm{e}}, \mathbf{M J} / \mathbf{k g}$ \\
\hline Methane & 50.8 & 50.0 \\
\hline Butane & 45.7 & 45.8 \\
\hline Methanol & 20.1 & 20.0 \\
\hline Ethanol & 27.3 & 27.1 \\
\hline PE & 43.8 & 44.6 \\
\hline Rubber & 42.1 & 42.4 \\
\hline PMMA & 25.2 & 25.0 \\
\hline PS & 39.5 & 40.0 \\
\hline PA-6 & 30.0 & 30.2 \\
\hline PET & 22.1 & 23.2 \\
\hline Xylan & 16.5 & 16.5 \\
\hline Cellulose & 16.2 & 16.1 \\
\hline Mannan & 16.2 & 16.1 \\
\hline Lignin & 24.7 & 24.8 \\
\hline
\end{tabular}

Thus, the best results give calculations by the equations (10) and (14).

\section{Energy Potential of Solid Polymer Materials and their Waste}

As is known, about 200-250 billion tons of biomass are created annually as a result of photosynthesis. Since biomass uses only $1 \%$ of the incident solar irradiation, then total amount of solar energy needed to create 200-250 billion tons of biomass can be estimated at 300-400ZJ, whereas amount of accumulated solar energy at 3000-4000EJ.

Most of the created biomass amount, $90 \%$, is decomposed in nature, and about $45-50 \%$ of the remaining biomass (wood, bast plants, cotton, cereals, technical crops, etc.) are used in industry and agriculture. Thus, the amount of unused biomass is about 1015 billion tons, which can be used as a source of alternative energy $[1,2]$.

The use of biomass as a solid fuel requires knowledge of its specific thermal energy, called also calorific value. Therefore, numerous attempts have been made to determine the calorific value of various types of biomass. Some of these studies have been performed with the use of precise calorimetric technique [43-45] (Table 5). The problem is that this technique is expensive and not always available; besides, direct measurements are complex and long. For this reason diverse express methods were developed to calculate the calorific value of various plant biomass. These methods are based on preliminary elemental and proximate analysis and well as determination of chemical composition, study structural characteristics and various properties of biomass samples [46-50].

Table 5: Experimental HHV and LHV of some biomass samples.

\begin{tabular}{|c|c|c|c|}
\hline Biomass type & $\mathbf{Q}, \mathbf{M J} / \mathbf{k g}$ & $\mathbf{q}, \mathbf{M J} / \mathbf{k g}$ & Ref. \\
\hline Pine & 20.0 & 18.8 & 43 \\
\hline Birch & 17.9 & 16.6 & 44 \\
\hline Maple & 18.5 & 17.1 & 44 \\
\hline Spruce & 18.6 & 17.2 & 44 \\
\hline Rosewood & 20.5 & 19.1 & 44 \\
\hline Wheat straw & 16.5 & 15.3 & 26 \\
\hline Rice husk & 15.9 & 14.8 & 45 \\
\hline
\end{tabular}

In contrast to plant polymers, the elemental composition of such complex composite as biomass cannot be calculated from chemical formula. Therefore, various experimental techniques (e.g. gas analyzer, etc.) are applied to determine the percentage of various elements in the plant materials. Proximate analysis of biomass allows determining the content of ash, volatile matter (VM), fixed carbon (FC). Standard methods of chemical analysis are known to determine percentage of cellulose, hemicelluloses, 
lignin and some other components, such as starch, pectin, proteins, extractives, etc. For example, the content of cellulose and hemicelluloses in biomass can be determined using the standard method NREL LAP-002, acid-insoluble lignin using the NREL LAP003, acid-soluble lignin using the NREL LAP-004, ash using the standard method NREL LAP-005 and extractives using the NREL LAP-010 [51,52]. Some correlation equations for estimating the HHV and LHV of different biomass types are presented in (Table $6 \& 7)$.

Table 6: Evaluation of HHV and LHV of biomass samples from analysis of elements (\%).

\begin{tabular}{|c|c|c|c|}
\hline Biomass type & $\mathbf{Q}, \mathbf{M J} / \mathbf{k g}$ & $\mathbf{q}, \mathbf{M J} / \mathbf{k g}$ & Ref. \\
\hline \multirow{2}{*}{ Wood } & $\mathrm{Q}=0.293 \mathrm{C}+5.205$ & $\mathrm{q}=0.270 \mathrm{C}+5.205$ & 53 \\
\hline \multirow{2}{*}{ Wood } & $\mathrm{Q}=0.306 \mathrm{C}+0.703 \mathrm{H}-0.0160+1.177$ & $\mathrm{q}=0.306 \mathrm{C}+0.660 \mathrm{H}-0.0160+1.177$ & 54 \\
\hline \multirow{2}{*}{ Forest residues } & $\mathrm{Q}=0.437 \mathrm{C}-1.670$ & $\mathrm{q}=0.407 \mathrm{C}-1.670$ & 53 \\
\hline \multirow{2}{*}{ Straw, husk } & $\mathrm{Q}=0.398 \mathrm{C}+0.093$ & $\mathrm{q}=0.370 \mathrm{C}+0.093$ & 55 \\
\hline \multirow{3}{*}{ Various biomasses } & $\mathrm{Q}=0.332 \mathrm{C}+0.851 \mathrm{H}-0.0360-0.049$ & $\mathrm{q}=0.332 \mathrm{C}+0.798 \mathrm{H}-0.0360-0.049$ & $26 \mathrm{C}+1.431 \mathrm{H}+0.093 \mathrm{~S}-0.024 \mathrm{~N}-1$ \\
\cline { 2 - 4 } & $\mathrm{Q}=0.295 \mathrm{C}+0.825 \mathrm{H}$ & $\mathrm{q}=0.295 \mathrm{C}+0.783 \mathrm{H}+360 \mathrm{H}+0.093 \mathrm{~S}-0.024 \mathrm{~N}-1$ & 27 \\
\cline { 2 - 4 } & $\mathrm{Q}=0.418(\mathrm{C}+\mathrm{H})-3.408$ & $\mathrm{q}=0.385(\mathrm{C}+\mathrm{H})-3.408$ & 56 \\
\hline
\end{tabular}

Table 7: Evaluation of HHV and LHV of biomass samples from proximate analysis.

\begin{tabular}{|c|c|c|c|}
\hline Biomass type & Q, MJ/kg & $\mathrm{q}, \mathrm{MJ} / \mathrm{kg}$ & Ref. \\
\hline Wood & $\begin{array}{c}Q=20.060-0.352 \text { Ash } \\
Q=23.885-(0.43 \text { Ash }+0.047 \mathrm{VM})\end{array}$ & $\begin{array}{c}q=18.780-0.352 \text { Ash } \\
q=22.213-(0.43 \text { Ash }+0.056 \text { VM })\end{array}$ & 53 \\
\hline Forest residues & $\begin{array}{c}Q=20.179-0.362 \text { Ash } \\
Q=22.608-(0.409 \text { Ash }+0.030 \mathrm{VM})\end{array}$ & $\begin{array}{c}q=18.766-0.362 \text { Ash } \\
q=21.025-(0.380 \text { Ash }+0.035 \mathrm{VM})\end{array}$ & 53 \\
\hline Husk, hulls & $\begin{array}{c}Q=20.353-0.234 \text { Ash } \\
Q=27.239-(0.306 \text { Ash }+0.089 \mathrm{VM})\end{array}$ & $\begin{array}{c}q=18.317-0.234 \text { Ash } \\
q=24.515-(0.306 \text { Ash }+0.095 \mathrm{VM})\end{array}$ & 53 \\
\hline Straw & $Q=18.960-0.225$ Ash & $q=17.164-0.225$ Ash & 57 \\
\hline Municipal waste & $\mathrm{Q}=0.356 \mathrm{VM}-6.998$ & $q=0.320 V M-6.998$ & 58 \\
\hline \multirow{7}{*}{$\begin{array}{l}\text { Various } \\
\text { biomasses }\end{array}$} & $Q=26.601-(0.304$ Ash $+0.082 \mathrm{VM})$ & $q=24.740-(0.304$ Ash $+0.096 \mathrm{VM})$ & 53 \\
\hline & $\begin{array}{c}Q=14.119+0.196 \mathrm{FC} \\
\mathrm{Q}=0.312 \mathrm{FC}+0.153 \mathrm{VM}\end{array}$ & $\begin{array}{c}\mathrm{q}=13.121+0.196 \mathrm{FC} \\
\mathrm{q}=0.312 \mathrm{FC}+0.140 \mathrm{VM}\end{array}$ & 59 \\
\hline & $\mathrm{Q}=0.354 \mathrm{FC}+0.171 \mathrm{VM}$ & $\mathrm{q}=0.354 \mathrm{FC}+0.152 \mathrm{VM}$ & 60 \\
\hline & $Q=19.914-0.232$ Ash & $\mathrm{q}=18.010-0.232$ Ash & 25 \\
\hline & $\mathrm{Q}=0.252 \mathrm{FC}+0.191 \mathrm{VM}$ & $\mathrm{q}=0.252 \mathrm{FC}+0.172 \mathrm{VM}$ & 26 \\
\hline & $Q=20.086-0.261$ Ash & $\mathrm{q}=18.340-0.261$ Ash & 56 \\
\hline & $\mathrm{Q}=0.354 \mathrm{FC}+0.156 \mathrm{VM}-0.008 \mathrm{Ash}$ & $\mathrm{q}=0.354 \mathrm{FC}+0.141 \mathrm{VM}-0.008 \mathrm{Ash}$ & 61 \\
\hline
\end{tabular}

The study of calculation methods based on proximate analysis showed that the equations containing percentage of Ash, VM and FC are insufficiently reliable, because the determination error of these parameters is quite high. More reliable results can be obtained using the equations based on the precise elemental analysis of a specific type of biomass. For example, equation of Tillman [54] is most suitable for calculating the heating value of wood samples, whereas equation of Grabovsky \& Bain [55,62] is most suitable for estimating the heating value of straw biomass. Calculations by means of "universal" equations averaging the results of various biomasses show a higher discrepancy with experiments than specific equations. Since an unlimited number of different types of biomass exists, an unlimited number of correlation equations is required to calculate the heating value. It is clear that such task is not feasible.

For this reason, another approach is proposed [63]. It is known that any plant biomass contains three natural biopolymers, cellulose, hemicelluloses and lignin, as well as extractives and some other substances. Thus, to evaluate the heating value of the biomass sample it is sufficient to determine the heating value of limited number of individual components and their content in the biomass, using the following equations:

$$
Q=\Sigma w_{i} Q_{i}
$$




$$
q=\Sigma w_{i} q_{i}
$$

where $Q_{i}$ and $q_{i}$ are HHV and LHV (NCH)of individual components in the biomass, which can be determined experimentally or calculated using eq. (7), (10) or (14) (Table 8); $w_{i}$ is mass fraction of the corresponding components in dry biomass sample (Table 9), which is determined by standard methods of chemical analysis $[51,52]$.

Table 8: HHV and LHV (NCH) of plant components.

\begin{tabular}{|c|c|c|}
\hline Component & $\mathbf{Q}, \mathbf{M J} / \mathbf{k g}$ & $\mathbf{q}, \mathbf{M J} / \mathbf{k g}$ \\
\hline Lignin & 26.0 & 24.7 \\
\hline Cellulose & 17.4 & 16.1 \\
\hline Hemicelluloses & 17.6 & 16.3 \\
\hline Starch & 17.5 & 16.2 \\
\hline Pectin & 13.7 & 12.8 \\
\hline Proteins & 22.2 & 21.1 \\
\hline $\begin{array}{c}\text { Extractives } \\
\text { (rosin, fats, oils, } \\
\text { waxes) }\end{array}$ & 38.6 & 36.5 \\
\hline Ash & 0 & 0 \\
\hline
\end{tabular}

Table 9: Chemical composition of some biomass samples $\left(w_{i}\right)$.

\begin{tabular}{|c|c|c|c|c|c|c|}
\hline Biomass & Cel & Hemi & Lig & Extr & Pro & Ash \\
\hline Softwood & 0.48 & 0.20 & 0.28 & 0.02 & 0.01 & 0.01 \\
\hline Hardwood & 0.45 & 0.25 & 0.23 & 0.03 & 0.01 & 0.03 \\
\hline Bagasse & 0.40 & 0.31 & 0.20 & 0.03 & 0.02 & 0.04 \\
\hline $\begin{array}{c}\text { Corn } \\
\text { stover }\end{array}$ & 0.37 & 0.33 & 0.20 & 0.02 & 0.02 & 0.06 \\
\hline $\begin{array}{c}\text { Cardboard } \\
\text { Newspaper }\end{array}$ & 0.60 & 0.12 & 0.18 & 0.03 & 0 & 0.07 \\
\hline $\begin{array}{c}\text { Wrapping } \\
\text { paper }\end{array}$ & 0.73 & 0.07 & 0.05 & 0.03 & 0 & 0.12 \\
\hline $\begin{array}{c}\text { Packaging } \\
\text { paper }\end{array}$ & 0.60 & 0.11 & 0.07 & 0.02 & 0 & 0.20 \\
\hline $\begin{array}{c}\text { Printing } \\
\text { paper }\end{array}$ & 0.62 & 0.05 & 0.01 & 0.02 & 0 & 0.30 \\
\hline
\end{tabular}

Note: Cel is Cellulose; Hemi is Hemicelluloses; Lig is Lignin; Extr is Extractives; Pro is Proteins

Using eq. (14) and (15), HHV and LHV of biomass samples can be easily calculated (Table 10).The results showed that this approach provides to calculate the heating values, which are close to experimental values.
Table 10: Calculated $\left(Q_{c}, q_{c}\right)$ and experimental $\left(Q_{e}, q_{e}\right)$ higher and lower heating values for some biomass samples.

\begin{tabular}{|c|c|c|c|c|}
\hline Biomass & $\mathbf{Q}_{\mathbf{c}^{\prime}} \mathbf{M J} / \mathbf{k g}$ & $\mathbf{Q}_{\mathrm{e}^{\prime}} \mathbf{M J} / \mathbf{k g}$ & $\mathbf{q}_{\mathbf{c}^{\prime}} \mathbf{M J} / \mathbf{k g}$ & $\mathbf{q}_{\mathrm{e}^{\prime}} \mathbf{M J} / \mathbf{k g}$ \\
\hline Softwood & 20.2 & 20.2 & 19.0 & 19.1 \\
\hline Hardwood & 19.6 & 19.7 & 18.5 & 18.4 \\
\hline Bagasse & 19.2 & 19.3 & 18.1 & 18.2 \\
\hline Corn stover & 17.8 & 17.7 & 17.4 & 17.5 \\
\hline Cardboard & 18.1 & 18.2 & 17.2 & 17.4 \\
\hline $\begin{array}{c}\text { Newspaper } \\
\text { (NP) }\end{array}$ & 19.3 & 19.5 & 18.2 & 18.2 \\
\hline $\begin{array}{c}\text { Wrapping } \\
\text { paper (WP) }\end{array}$ & 16.5 & 16.7 & 15.3 & 15.4 \\
\hline $\begin{array}{c}\text { Packaging } \\
\text { paper PA) }\end{array}$ & 15.0 & 15.0 & 14.2 & 14.0 \\
\hline $\begin{array}{c}\text { Printing } \\
\text { paper (PP) }\end{array}$ & 12.8 & 13.0 & 11.8 & 12.0 \\
\hline $\begin{array}{c}\text { Mixed } \\
\text { paper } \\
\text { (MP)* }\end{array}$ & 16.0 & & 14.9 & \\
\hline
\end{tabular}

Note: MP is mixture of NP, WP, PA and PP

The obtained results are confirmed by literature data (Table 11).

Table 11: Higher heating value for some biomass samples.

\begin{tabular}{|c|c|c|}
\hline Biomass & Q,MJ/kg & Ref. \\
\hline Softwood & $20.1-20.3$ & $41 ; 64$ \\
\hline Newspaper & $19.3-19.7$ & $65 ; 66$ \\
\hline Cardboard & $18.0-18.9$ & $66 ; 67$ \\
\hline Magazines from PP & $12.7-13.5$ & $66 ; 67$ \\
\hline
\end{tabular}

Currently, around 400 million tons of paper and cardboard (PB) are produced worldwide. However, after usage these PB materials are thrown out and pollute the environment. In economically developed countries such as the USA, Canada, Western Europe, Japan and some others, about $50 \%$ of the waste PB, mainly cardboard, is recycled. In Russia and China volume of recycled $\mathrm{PB}$ is $20-30 \%$. Unlike these countries, most Asian, African and Latin America countries almost do not recycle the waste PB. Thus, with an average of $75 \%$ of the waste BP or around 300 million tons in the world are land filled or burned.

As is known, the decomposition of PB and other organic waste in dumps leads to emission of methane, which is recognized 20 times more dangerous greenhouse gas than carbon dioxide $[67,68]$. Therefore, it is more preferable to burn the waste PB to reduce the area of landfills, decrease $\mathrm{CH}_{4}$ emission and produce heat or electricity [69]. For this purpose, it is necessary to know energetic characteristics of the waste. The statistical analysis showed that the average net combustion heat of paper trash is $15 \mathrm{MJ} / \mathrm{kg}$ in the dry state [67], which corresponds to LHV of mixed waste paper (Table 10). In fact, a paper trash is always wet and contains inorganic admixtures (ash); therefore its energy potential is less than for dry and pure material (Figure 1). 


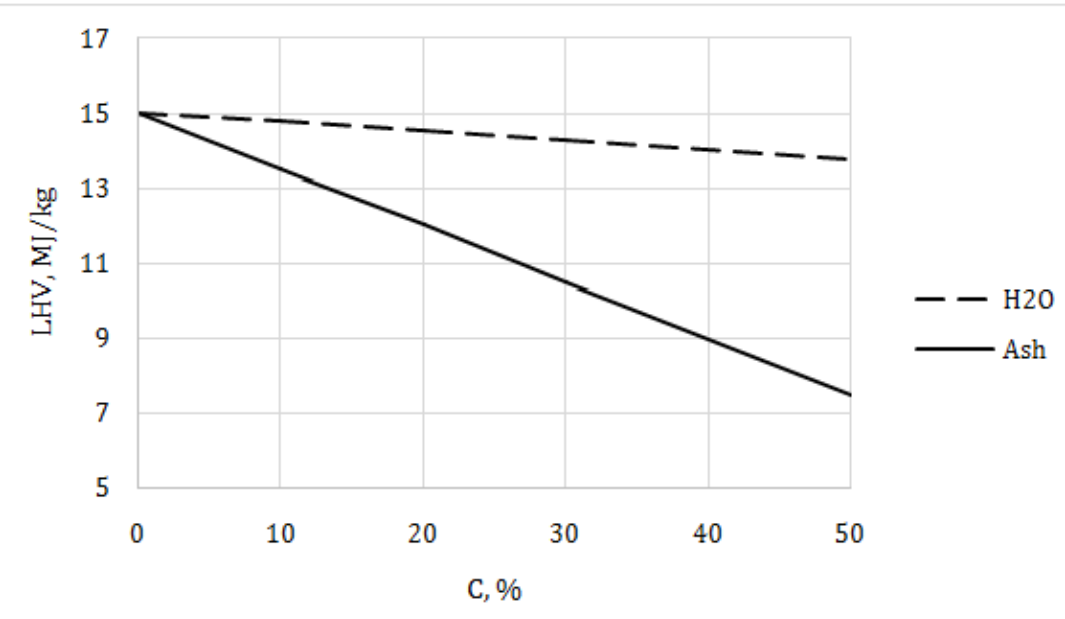

Figure 1: Dependence of LHV of waste paper on content of moisture or ash.

An acute environmental problem is the accumulation of synthetic polymers and their composites - plastics, which, unlike biomass, are biostable and can persist in nature for hundreds of years [70]. Every year in the world about 250-300 million tons of synthetic polymers and plastics are manufactured [22]. Over $90 \%$ of all plastic products are made of rubber, polyethylene (PE), polypropylene (PP), polystyrene (PS) and polyethylene terephthalate (PET).Only part, 30-35\%, of these waste, mainly PET-bottles, rubber tires and some other polymeric articles, is recycled in the world. But about $65-70 \%$ or $150-170$ million tons of biostable polymers and plastics are thrown away annually and pollute the environment. The dumps occupy huge areas, which are required for economy of countries. Moreover, in order to equip the dump and keep it at the level of modern environmental requirements, large funds are needed. Landfill sites are sources of pollution of the environment with harmful substances contained in plastics such as monomers, plasticizers, cross linkers, flame retardants, etc. Particularly dangerous are small particles of plastics. These pollutants poison the air, soil, water, and create a danger to the vital activity of plants, animals and people.

A huge problem is the pollution of water bodies and oceans with polymer debris [23]. Every year, up to 10 million tons of plastics are thrown into the ocean. It was found that currently more than 7 billion tons of biostable plastic waste have been accumulated in the world. The cardinal way of destroying plastic debris is burning. Despite $\mathrm{CO}_{2}$ emission, the modern technology of burning (e.g. in plasmatrons) causes less harm to the environment than the accumulation of huge volumes of biostable waste plastics. Along with the eliminating plastic debris, this method allows to receive an additional energy.

The specific thermal energy of synthetic polymers and plastics can be determined experimentally using calorimetric bomb or calculated by eq. (6), (9) or (13) (Table 2 \& 4). Typical HHV and LHV of the most spread synthetic polymers are shown in Table 12.
Table 12: HHV and LHV (NCH) of some synthetic polymers.

\begin{tabular}{|c|c|c|c|}
\hline Sample & $\mathbf{Q}, \mathbf{M J} / \mathbf{k g}$ & $\mathbf{q}, \mathbf{M J} / \mathbf{k g}$ & Ref. \\
\hline Rubber & 45.0 & 42.4 & 67,71 \\
\hline PE & 47.1 & 44.6 & 36 \\
\hline PP & 47.1 & 44.6 & 36 \\
\hline PS & 41.7 & 40.0 & 36 \\
\hline PMMA & 26.8 & 25.0 & 36 \\
\hline PET & 24.1 & 23.2 & 36 \\
\hline PVC & 22.7 & 19.2 & 67,71 \\
\hline PA-6 & 32.8 & 30.2 & 36 \\
\hline
\end{tabular}

Thus, polyolefins (POL) and rubber (RUB) have higher potential of heat energy than oxygen-, nitrogen- or halogencontaining plastics (PMMA, PET, PA-6, PVC). The last four plastics should be pulled out from plastic trash before combustion of POL, RUB or mixture thereof.

As is known, waste of biomass and plastics have different sizes, shapes and composition, as well as low bulk density. These features of solid organic matters leads to unsatisfactory fuel properties such as unstable calorific value, poor energetic density and insufficient combustion efficiency $[72,73]$. For example, trash of biomasscan have moisture from 10 to $55 \%$. Some biomass residue or waste, e.g. rice straw or husk, packaging and printing paper, contain from 15 to $30 \%$ of mineral components that hinder combustion and reduce calorific value. The bulk density of biomass varies from $40-80 \mathrm{~kg} / \mathrm{m}^{3}$ (grasses), to $150-200 \mathrm{~kg} / \mathrm{m}^{3}$ (wood chips), whereas the energy density is relative low, from 0.5 to $5 \mathrm{GJ} / \mathrm{m}^{3}$. Plastics trash also contain pieces of various sizes and shapes of different polymers with low bulk density, from 50 to $200 \mathrm{~kg} / \mathrm{m}^{3}$ that lead to low energy density, from 2 to $6 \mathrm{GJ} / \mathrm{m}^{3}$. The negative features of waste materials hinder their application as solid fuels for the energy recovery. To overcome the low energetic density and other negative fuel characteristics, the loose matters should be converted into dense pellets or granules. 
Pelletization of plant biomass is a well-known process, which includes a number of steps: selection, removal of foreign pieces, drying to a moisture content of $10 \%$ or less, shredding, grinding to particle size of 1 to $3 \mathrm{~mm}$, hot pressing at $80-90^{\circ} \mathrm{C}$ into long rod, cooling and cutting of the rod into pellets [73].The mineralized and very wet materials must be previously removed at the selection step. The pellets can be easily prepared from waste and residues of various plant materials, but especially from feed stocks having low moisture and ash content, as well as increased content of lignin and lipids $[1,74]$. The raw material for the production of granules is plastic waste. After disposal of PET bottles from trash, the remained waste contains mainly polyolefins having average $\mathrm{HHV}=42 \mathrm{MJ} / \mathrm{kg}$. Processing of plastic waste comprises steps of removal of foreign materials, shredding, melting and granulating.

The prepared pellets and granules are strong and dense; they have a typical bulk density of $600-700 \mathrm{~kg} / \mathrm{m}^{3}$ and energy density of $10-12 \mathrm{GJ} / \mathrm{m}^{3}$ for biomass pellets and $20-30 \mathrm{GJ} / \mathrm{m}^{3}$ for plastic granules. Such densified solid fuels represent a promising source of additional heat energy with improved burning productivity. Besides, the compacted solid fuels are more economical to transportation [75].

The granulation technology makes it possible to obtain fuel granules with unique properties from mixed materials containing both plastic and biomass waste [76]. The addition of plastic to biomass reduces hydrophility and increases the strength, density of energy and calorific value of the mixed solid fuel as compared to biomass pellets only. Furthermore, since the plant biomass is neutral for $\mathrm{CO}_{2}$ - emission, burning of granules made from mixed natural and synthetic materials results in a lower release of this greenhouse gas in comparison with a separate burning of plastic granules only.

Total amount of biomass aimed especially for energy production is estimated at 7-8 billion tons with energetic potential of 100-120EJ [77]. However, currently only half of this potential, $50-60 \mathrm{EJ}$, is used to recovery energy from biomass, i.e. about $10 \%$, of the global energy production [19]. Currently, biomass is remained the main source of energy for population living in rural areas of various countries, which uses firewood, chips, sawdust, twigs, bushes, straw, and other plant residues as solid biofuel to meet their energy needs. Share of biomass energy use in developing counties is $75 \%$ and in developed counties is $25 \%$ [77]. Besides, in economically developed countries the biomass waste is burned as a part of MSW in order to eliminate solid waste, reduce area of dumps, prevent environmental pollution and generate additional energy [78]. Combined heat and power systems that use the biomass-based fuel are widespread in Europe and especially in the Scandinavian counties [79]. In North America and European countries the thermal energy is generated also by burning of waste from forest and paper industry, as well as by burning of fuel pellets. Global production volume of the pellets is about 30 million tons; moreover, the growth of the production of such biofuel is expected to 50 million tons by 2020 [74].
As for plastics, it is known that over the last 70 years about 7 billion tons of wastes of various biostable plastics have been accumulated in the world, not counting another 150-170 million tons plastic waste that are thrown out every year. If gradually incinerate this amount of waste for 10 years, about 24-25EJ of thermal energy can be produced each year, whereas burning of another 150-170 million tons of plastic waste gives 6-7EJ of additional energy.

Thus, the total energetic potential of biomass and plastic wastes is estimated at 140-150EJ per year, which can provide 22$25 \%$ of the global energy production. Moreover, to produce the thermal energy it is most promising to burn the granulated mixed fuel containing biomass and additive of plastic waste.

\section{Energy Potential of Liquid and Gaseous Fuels Extracted from Solid Polymer Materials}

Solid polymer materials can be also converted into liquid and gaseous fuels. For example, such known liquid fuel as ethanol is produced from cellulose and various types of plant biomass. Technology of cellulosic ethanol comprises three steps. The first step is hydrolysis of cellulose with acids or cellulolytic enzymes to obtain glucose:

$$
\left(\mathrm{C}_{6} \mathrm{H}_{10} \mathrm{O}_{5}\right)_{n}+n \mathrm{H}_{2} \mathrm{O} \rightarrow n \mathrm{C}_{6} \mathrm{H}_{12} \mathrm{O}_{6}
$$

The second step is fermentation of glucose into ethanol in the presence of yeast:

$$
\mathrm{C}_{6} \mathrm{H}_{12} \mathrm{O}_{6} \rightarrow 2 \mathrm{C}_{2} \mathrm{H}_{5} \mathrm{OH}+2 \mathrm{CO}_{2}
$$

And the final stage is distillation and dehydration of ethanol.

The theoretical yield of ethanol is $51 \%$ from mass of glucose and about $57 \%$ from mass of cellulose, but the actual yield is lower.

A more difficult task is to obtain ethanol from biomass. This is due to the dense structure of plant materials and barrier properties of lignin, which hinder the diffusion of hydrolyzing reagents - acid or enzyme [80,81]. Therefore, a pretreatment step is applied to make the biomass more accessible to reagents. The main objectives of pretreatment are to loosen the physical structure of biomass and to eliminate the lignin in order to increase accessibility of biomass and the percentage of cellulose fraction. Various pretreatment methods of lingo cellulosic biomass can be used such as steam explosion, acidic treatment, alkaline extraction, oxidation, organosolv and some others [8184]. Among various methods, alkaline pretreatment of plant biomasses under mild conditions is intensively studied due to their industrial feasibility, relatively low capital investment, as well as low consumption of chemicals and energy [83-85]. Twostep pretreatment using combinations of acid and alkali are considered as very effective $[86,87]$.

Hydrolysis step of cellulose in pretreated biomass is usually carried out by cocktail of cellulolytic enzymes, which provide a higher yield of glucose than acid hydrolysis. This cocktail consists 
of three main enzyme types, endoglucanase, exo-glucanase and beta-glycosidase, acting synergistically [80].

Known types of enzymatic cocktails are CellicCTec 2 and CellicCTec 3 of Novozymes, as well as Accellerase-1500 and GC220 of DuPont/Genencor. Optimal conditions of the enzymatic hydrolysis are the following: temperature is 45 to $50^{\circ} \mathrm{C}, \mathrm{pH}=4.5$ to 5.0 , dose of enzymes is 10 to $20 \mathrm{mg}$ per $1 \mathrm{~g}$ of solid biomass and loading of biomass substrate is $140-160 \mathrm{~g} / \mathrm{L}$.

The fermentation of glucose solution obtained after enzymatic hydrolysis of the pretreated biomass is carried out usually by the yeast of Saccharomyces cerevisiae in the presence of nutrients at $30{ }^{\circ} \mathrm{C}$ and $\mathrm{pH}=5$ [88].Various fermentation methods can be used: simultaneous saccharification and fermentation, simultaneous saccharification and co-fermentation, sequential fermentation, continuous fermentation, etc. The final concentration of ethanol after fermentation step is usually $50-60 \mathrm{~g} / \mathrm{L}$. Therefore the dilute "beer" is distilled to obtain $95-96 \%$ of ethanol. Since the fuel ethanol should not contain more than $1 \%$ water, the distilled ethanol is dehydrated to $99 \%$ using dewatering agents, e.g. zeolites. The yield of ethanol at the same saccharification and fermentation conditions depends on type of biomass and pretreatment method. For example, yield of ethanol from alkali pretreated corn stover is $30-35 \%$ that is $18-21 \%$ from initial biomass.

Hydrolyzate of cellulose or pretreated biomass containing glucose can be fermented also by oleaginous microorganisms for lipid production. They are yeasts of Rhorosporidiumtoruloides, Lipomycesstarkeyi, Mortierellaisabellina, Trichosporonfermentans, Cryptococcus curvatus etc. $[89,90]$. The fermentation of glucose solution with oleaginous yeasts was carried out at $30^{\circ} \mathrm{C}$ while stirring for 4-7 days. As results, from 20 to $50 \%$ of glucose are converted to lipids, which further can be uses for production of biodiesel fuel [91,92].

The technology of biodiesel fuel is based on transesterification reaction between lipid and alcohol, e.g. methanol, in the presence of alkaline or acid catalysts $[93,94]$ :

$$
\mathrm{C}_{3} \mathrm{H}_{5}\left(\mathrm{O}_{2} \mathrm{CR}\right)_{3}+3 \mathrm{CH}_{3} \mathrm{OH} \rightarrow 3 \mathrm{RCO}_{2} \mathrm{CH}_{3}+\mathrm{C}_{3} \mathrm{H}_{5}(\mathrm{OH})_{3}
$$

The obtained ester is used as a biodiesel fuel, and the byproduct, glycerol, can be utilized for some other applications.

Anaerobic digestion of biomass allows to obtain biogas such as methane. The most appropriate feed stocks for biogas production are waste paper or residue of pulp and paper industry. Lignocellulosic biomass can be pretreated to loosen the physical structure of substrate and reduce content of lignin hindering the bioconversion process [95]. The dilute aqueous dispersion of substrate $(5-10 \%)$ is digested in a bioreactor under anaerobic conditions at optimal $\mathrm{pH}$ of 6.8-7.4 under the action of mesophilic bacteria at temperature of $30-40{ }^{\circ} \mathrm{C}$ or thermophilic bacteria at temperature of $50-60{ }^{\circ} \mathrm{C}$. The source of these bacteria can be sludge of sewage or cattle manure. The process of anaerobic biodegradation usually takes 2.5 to 3 weeks.
The process of anaerobic biodegradation of organic substances occurs in several stages [96]. In the first stage, hydrolysis, the complex molecules (CM) of organic substances break down into simple molecules (SM). In the second stage, acetogenesis, simple molecules produced in the first stage are converted to acetic acid (AA). In the last stage, methanogenesis, acetic acid is converted to biogas (BG) containing methane, carbon dioxide and some other gases.

$$
C M \rightarrow S M \rightarrow A A \rightarrow B G
$$

For example, cellulose and other C6-polysacharides (C6 PS) are hydrolyzed into monomeric glucose (GL). Further, glucose forms acetic acid, which is transformed into biogas.

$C 6 P S \rightarrow G L \rightarrow A A \rightarrow B G$

(1). $\mathrm{C}_{6} \mathrm{H}_{10} \mathrm{O}_{5}+\mathrm{H}_{2} \mathrm{O} \rightarrow \mathrm{C}_{6} \mathrm{H}_{12} \mathrm{O}_{6}$

(2). $\mathrm{C}_{6} \mathrm{H}_{12} \mathrm{O}_{6} \rightarrow 3 \mathrm{CH}_{3} \mathrm{COOH}$

(3). $3 \mathrm{CH}_{3} \mathrm{COOH} \rightarrow 3 \mathrm{CH}_{4}+3 \mathrm{CO}_{2}$

Total process: $\mathrm{C}_{6} \mathrm{H}_{10} \mathrm{O}_{5}+\mathrm{H}_{2} \mathrm{O} \rightarrow 3 \mathrm{CH}_{4}+3 \mathrm{CO}_{2}$

The anaerobic digestion of xylan and others C5-polysacharides (pentosans) can be described as follows:

(1). $\mathrm{C}_{5} \mathrm{H}_{8} \mathrm{O}_{4}+\mathrm{H}_{2} \mathrm{O} \rightarrow \mathrm{C}_{5} \mathrm{H}_{10} \mathrm{O}_{5}$

(2). $\mathrm{C}_{5} \mathrm{H}_{10} \mathrm{O}_{5} \rightarrow 2.5 \mathrm{CH}_{3} \mathrm{COOH}$

(3). $2.5 \mathrm{CH}_{3} \mathrm{COOH} \rightarrow 2.5 \mathrm{CH}_{4}+2$.

Total process: $\mathrm{C}_{5} \mathrm{H}_{8} \mathrm{O}_{4}+\mathrm{H}_{2} \mathrm{O} \rightarrow 2.5 \mathrm{CH}_{4}+2.5 \mathrm{CO}_{2}$

The theoretical yield of biogas $\left(Y_{b g}\right)$, containing mixture of $\mathrm{CH}_{4}$ and $\mathrm{CO}_{2}$, and methane only $\left(Y_{m}\right)$ from 1 t of dry organic substance (DOS) with molecular weight, $\mathrm{M}$ ( $\mathrm{g} / \mathrm{mole})$, can be calculated by the equations [97]:

$$
\begin{aligned}
& Y_{b g}\left(m^{3} / t\right)=22400 M^{-1}(m+k) \\
& Y_{m}\left(m^{3} / t\right)=22400 M^{-1} m
\end{aligned}
$$

Where $\mathrm{m}$ and $\mathrm{k}$ is number of moles of $\mathrm{CH}_{4}$ and $\mathrm{CO}_{2}$, respectively, formed from 1 mole of DOS.

Using Eq (16) and (17) it can be calculated that the theoretical yield of biogas from $1 \mathrm{t}$ of cellulose and other C6 PS is $830 \mathrm{~m}^{3}$ and of methane is $415 \mathrm{~m}^{3}$. In the case of pentosans the theoretical yield of biogas is $848 \mathrm{~m}^{3}$, whereas of methane is $424 \mathrm{~m}^{3}$ from $1 \mathrm{t}$ of DOS. Maximum yield of biogas from $1 \mathrm{t}$ of biomass, containing $65 \%$ of polysaccharides (PS), is about $546 \mathrm{~m}^{3}$ and of methane $273 \mathrm{~m}^{3}$.However, the actual yield of biogas and methane from plant polymers and biomass for real time of bioconversion is significantly lower. For example, bacterial digestion of $1 \mathrm{t}$ wheat straw with $65 \%$ content for 3 weeks of polysaccharides results in the production of about $150 \mathrm{~m}^{3}$ methane, i.e. $55 \%$ from theoretical yield.

Biomass of microalgae is promising raw-material for bioenergy recovery. Microalgae (MA) include variety of species 
such as Ankistrodesmus, Botryococcus. Chlorella, Nannochloropsis, Neochloris, Nitzschia, Scenedesmus, Schizochytrium etc. The peculiarity of MA is that they contain lipids. Among them Schizochytrium, Nannochloropsis and Botryococcus contain particularly high amount of lipids up to 70-75\% [98]. Extracted lipids are used for production of biodiesel fuel through transesterification reaction $[99,100]$. The residual biomass of MA remaining after extraction of lipids can be burned or subjected to anaerobic digestion to produce biogas [101].

Liquid and gaseous fuels are obtained also by pyrolysis of biomass or plastics. Biomass wastes and residues are subjected usually for this purpose. The main products of the pyrolysis are bio-oil, gases and charcoal $[102,103]$. The yield of various products is dependent on conditions of the pyrolysis process and biomass composition. Slow pyrolysis of the biomass is carried out at heating rate $\leq 1 \mathrm{degree}$ per sec up to $400-500{ }^{\circ} \mathrm{C}$ and typical residence time of 10 to $20 \mathrm{~min}$ with formation of 20 to $40 \%$ biooil, 30 to $50 \%$ gases and 25 to $35 \%$ charcoal. If the pyrolysis temperature is above $500{ }^{\circ} \mathrm{C}$, a decrease in the yield of charcoal is observed. Slow pyrolysis of biomass at high temperatures, 800 to $1000{ }^{\circ} \mathrm{C}$ in the inert or steam atmosphere causes the formation mainly gaseous product containing $\mathrm{CO}_{2}, \mathrm{CO}, \mathrm{H}_{2}, \mathrm{CH}_{4}$ and some other gases with calorific value $10-12 \mathrm{MJ} / \mathrm{Nm}^{3}$ or $14-16 \mathrm{MJ} / \mathrm{kg}$ [104].

Fast pyrolysis is performed at heating rate 100-200degrees per sec, temperature above $800{ }^{\circ} \mathrm{C}$ and short residence time especially to increase the yield of bio-oil. Flash pyrolysis at heating rate above 1000 degrees per sec and temperature above $1000{ }^{\circ} \mathrm{C}$ allows obtain the bio-oil with a high yield of $70-75 \%$. The calorific value of the bio-oil is $15-17 \mathrm{MJ} / \mathrm{kg}$, which is significantly lower than of ethanol, biodiesel and hydrocarbon fuels [1]. Pyrolysis method is used also for decomposition of waste plastics to obtain combustible liquids-pyrolytic hydrocarbons (HC) $[105,106]$. Calorific values of various liquid and gases extracted from biomass or plastics are shown in Table 13.

Table 13: LHV of some liquids and gases extracted from polymer materials.

\begin{tabular}{|c|c|}
\hline Liquid or gas & $\mathbf{q}, \mathbf{G J} / \mathbf{t}$ \\
\hline Ethanol & 27 \\
\hline Lipids & 37 \\
\hline Bio-oil & 16 \\
\hline Biodiesel fuel & 37 \\
\hline Pyrolytic HC & 40 \\
\hline Methane & 50 \\
\hline Pyrolytic gas of BM & 15 \\
\hline
\end{tabular}

These values were used to calculate the energy yield (EY):

$$
E Y=100 Y q / q_{o}(18)
$$

Where $\mathrm{Y}$ is yield of liquid or gas $(\mathrm{t})$ obtained from $1 \mathrm{t}$ of initial polymer material; $q$ is $\mathrm{LHV}$ of liquid or gas $(\mathrm{GJ} / \mathrm{t})$, and $\mathrm{q}_{0}$ is $\mathrm{LHV}$ of initial polymer material $(\mathrm{GJ} / \mathrm{t})$

Knowledge of the energy yield allows to understand that it is more advantageous, the direct burning of the starting polymer material (biomass or plastic), or the burning of various liquid or gaseous fuels extracted from this material? The typical examples of energy recovery are presented in Table 14.

Analysis of these typical examples reveals that in all cases the energy yield of liquid or gaseous products extracted from 1 t of starting materials (biomass or plastic) is significantly lower than the thermal energy of $1 \mathrm{t}$ of the starting materials (Table 14), (Figure 2).

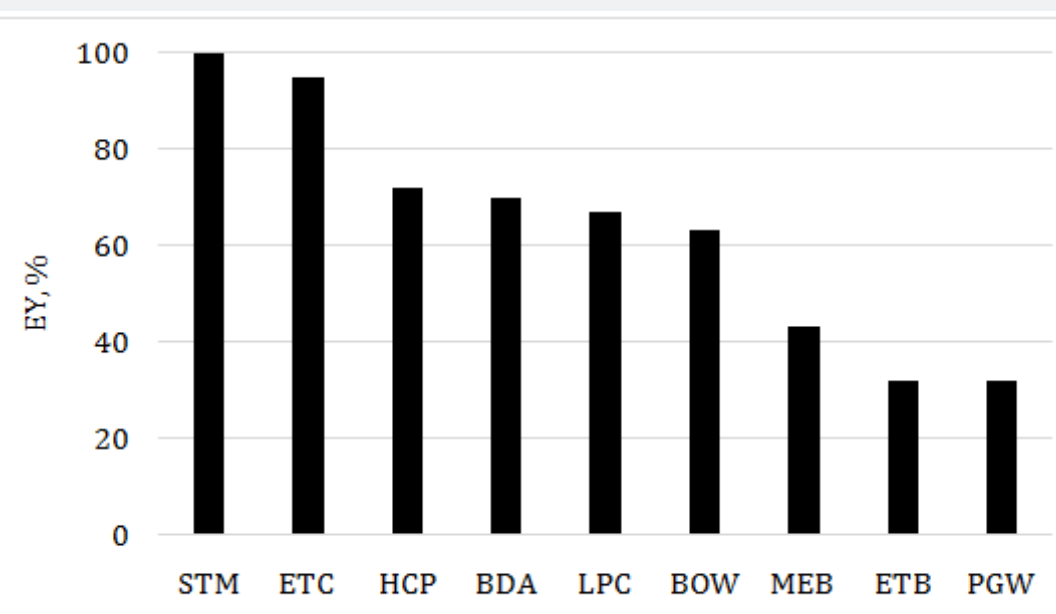

Figure 2: Energy yield (EY) of combustible liquids or gases extracted from starting material (STM):

Ethanol from cellulose (ETC), Hydrocarbons from polyolefins (HCP), Biodiesel fuel from micro-algae (BDA), Lipids from cellulose (LPC), Bio-oil from woody sawdust (BOW), Methane from biomass (MEB), Ethanol from biomass (ETB) and Pyrolytic gases from woody sawdust (PGW) 
Table 14: Maximum energy yield (EY) of some liquids and gases extracted from polymermaterials.

\begin{tabular}{|c|c|c|c|c|c|}
\hline Process & Product & $\mathbf{Y}$ & $\mathbf{q}, \mathbf{G J} / \mathbf{t}$ & qo, GJ/t & EY, \% \\
\hline Bioethanol obtained by saccharification of cellulose and fermentation of glucose & Ethanol & 0.57 & 27 & 16.1 & 95 \\
\hline $\begin{array}{l}\text { Bio ethanol obtained by saccharification of alkali pretreated corn stover and } \\
\text { fermentation of glucose }\end{array}$ & Ethanol & 0.21 & 27 & 17.6 & 32 \\
\hline $\begin{array}{l}\text { Lipids obtained by saccharification of cellulose and fermentation of glucose by } \\
\text { oleaginous yeast }\end{array}$ & Lipids & 0.29 & 37 & 16.1 & 67 \\
\hline Biodiesel fuel obtained from microalgae & Biodiesel & 0.50 & 37 & 26.5 & 70 \\
\hline Bio-oil obtained by flash pyrolysis of woody sawdust & Bio-oil & 0.75 & 16 & 19.0 & 63 \\
\hline Methane obtained by anaerobic digestion of corn stover & Methane & 0.15 & 50 & 17.6 & 43 \\
\hline Pyrolytic gas (PG) obtained by slow pyrolysis of woody sawdust & PG & 0.40 & 15 & 19.0 & 32 \\
\hline Pyrolytic HC obtained by slow pyrolysis of polyolefins & $\mathrm{HC}$ & 0.80 & 40 & 44.6 & 72 \\
\hline
\end{tabular}

Thus, to generate the thermal energy, it is more profitable to burn the starting material as solid fuel, than extracted liquid or gaseous fuels.

\section{Conclusion}

The energy potential of natural and synthetic polymers, plant biomass, plastics and their solid waste, as well as combustible liquids and gases derived from them has been studied. To determine calorific values of solid, liquid and gaseous substances various experimental and calculation methods were used. For this purpose, improved equations based on chemical structure and elemental analysis was proposed. It was shown that conversion of solid materials into liquids or gases decreases the yield of thermal energy. Therefore for the production of thermal energy, it is more profitable to burn the solid biomass or plastic than combustible liquids and gases, derived from them. Studies have shown that lipids and lignin increase, whereas moisture and ash reduce the calorific value of biomass. The calorific value of most synthetic polymers and plastics is higher than that of biomass samples, but resources of waste plastics are about 10 times lower than these of biomass. It is most promising to burn the granulated mixed fuel containing biomass and about $10 \%$ additive of plastic waste, since it enables to increase calorific value and energy density of biomass, as well as to reduce emission of carbon dioxide in comparison with separate incineration of plastic only. Considering the total amount of biomass and plastics waste destined for combustion, it was calculated that current annual energy potential of biomass is about $115 \mathrm{EJ}$, and of plastic waste about $30 \mathrm{EJ}$, which can cover together about $24 \%$ of the world's annual energy production. The problem is that plastics are produced from fossil raw materials, whose reserves are not sustainable and permanently depleted. In this regard, the wider use of biomass has a significant advantage because their reserves in nature are huge and continuously renewed. In the near future, it is planned to increase the share of biomass in the production of alternative energy twice at least, which can simultaneously contribute to reducing in green house gas emission and improving the ecological state of the environment.

\section{References}

1. Ioelovich M (2015) Recent findings and the energetic potential of plant biomass as a renewable source of biofuels - a review. Bioresources 10(1): 1879-1914.

2. Ioelovich M (2013) Plant Biomass as a Renewable Source of Biofuels and Biochemicals. LAP: Saarbrücken. p. 52.

3. Saidur R, Abdelaziz EA, Demirbas A, Hossain MS, Mekhilef S (2011) A review on biomass as a fuel for boilers. Renewable and Sustainable Energy Reviews 15(5): 2262-2289.

4. Klemm D, Heublein B, Fink HP, Bohn A (2005) Cellulose: fascinating biopolymer and sustainable raw material. Angew Chem 44(22): 2-37.

5. Hon D, Shirashi N (2001) Wood and Cellulose Chemistry. Marcel Dekker: New York, USA. pp. 914.

6. Ioelovich M (2014) Cellulose: Nanostructured Natural Polymer. LAP: Saarbrücken. p. 88

7. Horn SJ, Vaaje-Kolstad G, Westereng B, Eijsink VG (2012) Novel enzymes for the degradation of cellulose. Biotech. Biofuel 5: 45-57.

8. Abbasi T, Abbasi SA (2010) Biomass energy and the environmental impacts associated with its production and utilization. Renew. Sustain. Energy Rev 14(3): 919-937.

9. Jahirul MI, Rasul MG, Chowdhury AA, Ashwath N (2012) Biofuels production through biomass pyrolysis. Energies 5(12): 4952-5001.

10. Chen F, Dixon RA (2007) Lignin modification improves fermentable sugar yields for biofuel production. Natur Biotechnol 25(7): 759-761.

11. Pan X, Xie D, Gilkes N, Gregg DJ, Saddler JN (2005) Strategies to enhance the enzymatic hydrolysis of pretreated softwood with high residual lignin content. Appl Biochem Biotechnol.121-124: 1069-1079.

12. Raven PH, Evert RF, Eichhorn SE (2005) Biology of Plants, ( $7^{\text {th }}$ edn). W. H. Freeman and Company: New York, USA pp. 686.

13. Blankenship RE (2014) Molecular Mechanisms of Photosynthesis. $\left(2^{\text {nd }}\right.$ edn). John Wiley \& Sons: Oxford, USA pp. 312.

14. Saxena IM, Brown RM (2005) Cellulose biosynthesis: current views and evolving concepts. Ann Bot 96(1): 9-21.

15. Lerouxel O, Cavalier DM, LiepmanA H, Keegstra K (2006) Biosynthesis of plant cell wall polysaccharides - a complex process. Current Opinion in Plant Biology 9: 621-630.

16. Sjöström E (1993) Wood Chemistry: Fundamentals and Applications. Academic Press: San Diego, USA pp. 293.

17. Boerjan W, Ralph J, Baucher M (2003) Lignin biosynthesis. Annu Rev Plant Biol 54 (1): 519-546. 
18. Ahuja D, Tatsutani M (2009) Sustainable energy for developing countries. Sapiens 2:1-16.

19. Ladanai S, Vinterbäck J (2009) Global Potential of Sustainable Biomass for Energy. SLU: Uppsala p. 29.

20. Hossain KA (2012) Global energy consumption pattern and GDP. Int J Renewable Energy Technol Res1: 23-29.

21. Lehtovaara M, Karvonen M, Kässi T (2013) The role of energy support schemes in renewable energy market penetration. Int J Renew Sustain Energy 2(2): 30-40.

22. Barnes DK A, Galgani F, Thompson RC, Barlaz M (2009) Accumulation and fragmentation of plastic debris in global environments.Philos. Trans. Royal Soc.B: Biological Sci 364: 1985-1998.

23. Hammer J, Kraak MH, Parsons J R (2012) Plastics in the marine environment: the dark side of a modern gift. Environmen. Contamin. Toxicology 220: 1-44.

24. Channiwala SA, Parikh PP (2002) A unified correlation for estimating HHV of solid, liquid and gaseous fuels. Fuel 81: 1051-1063.

25. Sheng C, Azevedo JLT (2005) Estimating the higher heating value of biomass fuels from basic analysis data. Biomass Bioenerg 28: 499-507.

26. Yin CY (2011) Prediction of higher heating values of biomass from proximate and ultimate analyses. Fuel 90: 1128-1132.

27. Demirbas A, Demirbas AH (2004) Estimating the calorific values of lignocellulosic fuels. Energy Explor Exploit 22:135-143.

28. Demirbas A (2006) Theoretical heating values and impacts of pure compounds and fuels. Energy Source 28: 459-467.

29. Friedl A, Padouvas E, Rotter H, Varmuza K (2005) Prediction of heating values of biomass fuel from elemental composition. Anal Chim Acta 544: 191-198.

30. Babrauskas V (1992) Heat Release in Fires. Ch.8. Elsevier: New York, USA pp. 251-255.

31. Chen Y, Frendi A, Tewari SS, Sibulkin M (1991) Combustion properties of pure and fire-retarded cellulose. Combust. Flame 84 (1-2):121-140.

32. Kabo GJ, Voitkevich OV, Blokhin AV, Kohut SV, Stepurko EN, et al. (2013) Thermodynamic properties of starch and glucose. J Chem Thermodynam 59: 87-93.

33. UryashV F, Larina VN, Kokurina NY, Novoselova NV (2010) The thermochemical characteristics of cellulose and its mixtures with water. Russ J Phys Chem 84: 915-921.

34. Goldberg RN, Schliesser J, Mittal A, Stephen DR, Filipa SA, et al. (2015) A thermodynamic investigation of the cellulose allomorphs. J Chem Thermodyn 81: 184-226.

35. Ioelovich M (2016) Study of thermodynamic stability of various allomorphs of cellulose. J Basic Appl Res Int 16(2): 96-103.

36. Walters RN, Lyon RE, Hackett SM (2000) Heats of combustion of hightemperature polymers. Fireand Mater 24: 1-13.

37. Schmidt Rohr K (2015) Why combustions are always exothermic yielding about $418 \mathrm{~kJ}$ per mole of $\mathrm{O}_{2}$. J Chem Educ 92: 2094-2099.

38. Ioelovich M (2017) Calculation of heating value of organic substances using oxygen consumption. J Basic Appl Res Int 21(4): 180-185.

39. Suris AL (2007) Heat of combustion of liquid halogen-organic compounds. Chem. Pertol Eng 43(1-2): 20-21.

40. MaksimukYu V, Kruk VS, Antonova ZA, Ponomarev DA, Sushkova AV (2016) Calculation of combustion heat of wood-based fuel using the elemental composition. Forest J 6: 110-121.
41. Parikh J, Channiwala SA, Ghosal GK (2005) A correlation for calculating HHV from proximate analysis of solid fuels. Fuel 84: 487-494.

42. Ioelovich M (2016) Comparison of methods for calculation of combustion heat of biopolymers. American J Appl Sci Eng Tech 1(2): 63-67.

43. Howard ET (1972) Heat of combustion of various southern pine materials. Wood Science 5(3): 194-197.

44. Günther B, Gebauer K, Barkowski R, Rosenthal M, Bues C T (2012) Calorific value of selected wood species and wood products. Europ J Wood and Wood Prod 70(5): 755-757.

45. Shen I, Zhu S, Liu X, Zhang H, Tan J (2012) Measurement of heating value of rice husk by using oxygen bomb calorimeter with benzoic acid as combustion adjuvant. Energy Procedia 17: 208-213.

46. Park S, Baker JO, Himmel ME, et al. (2010) Cellulose crystallinity index: measurement techniques and their impact on interpreting cellulase performance. Biotechnology for Biofuels 3: 1-10.

47. Arin G, Demirbas A (2004) Mathematical modeling the relations of pyrolytic products from lingo cellulosic materials. Energy Source 26: 1023-1032.

48. Erol M, Haykiri Acma H, Küc, ükbayrak S (2010) Calorific value estimation of biomass from their proximate analyses data. Renew Energy 35: 170-173.

49. Shen J, Zhu S, Liu X, Zhang H, Tan J (2010) The prediction of elemental composition of biomass bases on proximate analysis. Energy Convers Manage 51(5): 983-987.

50. Vargas Moreno J M, Callejón Ferre A J, Pérez-Alonso J, Velázquez Martî́ B (2012) A review of the mathematical models for predicting the heating value of biomass materials. Renew Sustain Energy Reviews 16: 3065-3083.

51. Sluiter JB, Ruiz RO, Scarlata CJ, Sluiter AD, Templeton DW (2010) Compositional analysis of lignocellulosic feedstocks,review and description of methods. J Agric Food Chem 58(16): 9043-9053.

52. Ioelovich M (2015) Methods for determination of chemical composition of plant biomass. SITA 17(4): 208-214.

53. Ebeling JM, Jenkins BM (1985) Physical and chemical properties of biomass. Trans ASAE 28: 898-902.

54. Tillman A D (1978) Wood as an Energy Source. Acad. Press: New York, USA. pp. 252.

55. Grabovsky M, Bain R (1981) Biomass gasification - principles and technology. Noyes: New Jersey, USA p. 41-69.

56. Callejón Ferre AJ, Velázquez-Martí B, López Martínez JA, Manzano Agügliaro F (2011) Greenhouse crop residues: energy potential and models for the prediction of their higher heating value. Renew Sust Energy Rev 15(2): 948-955.

57. Huang CJ, Han LJ, Liu X, Yang Z (2008) Models predicting calorific value of straw from the ash content. Int J Green Energy 6: 533-539.

58. Kathiravale S, Yunus MN, Sopian K, et al. (2003) Modeling the heating value of municipal solid waste. Fuel 82: 1119-1125.

59. Demirbas A (1997) Calculation of higher heating values of biomass fuels. Fuel 76: 431-434

60. Cordero T, Márquez F, Rodríguez Mirasol J, Rodríguez JJ (2001) Predicting heating values of lignocellulosics and carbonaceous materials from proximate analysis. Fuel 80: 1567-1571.

61. Parikh J, Channiwala SA, Ghosal GK (2005) A correlation for calculating HHV from proximate analysis of solid fuels. Fuel 84: 487-494. 
62. Bychkov AL, Denkin AI Tihova VD, Lomovsky OI (2014) Prediction of higher heating values of lignocellulose from elemental analysis. Chem. Plant Raw Mater 3: 99-104.

63. Ioelovich M (2017) Comparison of methods for calculation of combustion heat of biopolymers. Chemistry of Plant Mater 2: 49-56.

64. Telmo C, Lousada J, Moreira N (2010) Proximate analysis, backwards stepwise regression between gross calorific value, ultimate and chemical analysis of wood. Biores Technol 101(11): 3808-3815.

65. Sørum L, Grønli M, Hustad, JE (2001) Pyrolysis characteristics and kinetics of municipal solid wastes. Fuel 80(9): 1217-1227.

66. Meraz L, Domínguez A, Kornhauser I, Rojas F (2003) A thermochemical concept-based equation to estimate waste combustion enthalpy from elemental composition. Fuel 82(12): 1499-1507.

67. Shi H (2015) Characterization, Heating Value Modeling and Pyrolysis Studies of Municipal Solid Wastes. University Press: Calgary pp. 106

68. Lou X, Nair J (2009) The impact of landfilling and composting on greenhouse gas emissions: a review. Biores. Technol 100(16): 37923798.

69. Lombardi L, Carnevale E, Corti, A (2015) A review of technologies and performances of thermal treatment systems for energy recovery from waste. Waste Management 37: 26-44.

70. Singh P, Sharma VP (2016) Integrated plastic waste management: environmental and improved health. Procedia Environment Sci 35 692-700.

71. Courtemanche B, Levendis YA (1998) A laboratory study on the NO, $\mathrm{NO}_{2}, \mathrm{SO}_{2}, \mathrm{CO}$ and $\mathrm{CO}_{2}$ emissions from the combustion of pulverized coal, municipal waste plastics and tires. Fuel 77(3): 183-196.

72. McKendry P (2002) Energy production from biomass: overview of biomass. Bioresour Technol 83(1): 37-46.

73. Stelte W, Sanadi AR, Shang L, et al. (2012) Recent developments in biomass pelletization - a review. Bioresources 7(3): 4451-4490.

74. Dhamodaran A, Afzal M (2013) Modeling and characterization of reed canary grass pellet formation phenomenon. Int J Renew Sustain Energy 2(2): 63-73.

75. Larsson SH, Thyrel M, Geladi P, Lestander, TA (2008) High quality biofuel pellet production from pre-compacted low density raw materials. Biores Technol 99(15): 7176-7182.

76. Ioelovich M (2014) Problems of solid biofuels made of plant biomass. Advance in Energy 2(1): 15-20.

77. Parikka M (2004) Global biomass fuel resources. Biomass and Bioenergy 27: 613-620.

78. Ionescu G, Rada, EC (2012) Material and energy recovery in a municipal solid waste system: practical applicability. Int J Env Res 1(1): 26-30.

79. Lehtovaara M, Karvonen M, Kässi T (2013) The role of energy support schemes in renewable energy market penetration. Int J Renew Sustain Energy 2(2): 30-40.

80. Horn SJ, Vaaje Kolstad G, Westereng B, Eijsink VG (2012) Novel enzymes for the degradation of cellulose. Biotechn Biofuel 5: 45-57.

81. Kautto J, Realff MJ, Ragauskas AJ, Kässi T (2014) Economic analysis of an organosolv process for bioethanol production.Bioresources 9(4): 6041-6072.

82. Xu L, Wang J, Sharma Shivappa R R, Cheng, J J (2011) Enzymatic hydrolysis of switchgrass and coastal Bermuda grass pretreated with different chemical methods. Bioresources 6(3): 2990-3003.
83. Bali G, Meng X, Deneff JI, Sun Q Ragauskas AJ (2014) The effect of alkaline pretreatment methods on cellulose structure and accessibility Chem Sust Chem 11: 1-5.

84. Bufalino L, Caixeta LA, Protásio TP, Scatolino MV, Mesquita RGA, et al. (2015) Options for chemical modification of wastes from a Brazilian hardwood species and potential applications. Key Eng Mater 634: 321328.

85. Hashmi M, Shah AA, Hameed A, Ragauskas AJ (2017) Enhanced production of bioethanol by fermentation of autohydrolyzed and C4mimOAc-treated sugarcane bagasse employing various yeast strains. Energies 10(8): 1207-1214.

86. Weerasai K, Suriyachai N, Poonsrisawat A, Arnthong J, Unrean P, et al. (2014) Sequential acid and alkaline pretreatment of rice straw for bioethanol fermentation. Bioresources 9(4): 5988-6001.

87. Ioelovich M (2018) Green chemistry and technology of plant biomass. SITA 20 (1): 3-12.

88. Lin Y, Tanaka S (2006) Ethanol fermentation from biomass resources: current state and prospects. Appl. Microbiol. Biotechnol 69(6): 627642.

89. Pirozzi D, Ausielloa A, Yousuf A (2014) Exploitation of oleaginous yeasts for the production of microbial oils from agricultural biomass. Chem. Eng. Transact 37: 469-474.

90. Martínez EJ, Raghavan, González-Andrés F, Gómez X (2015) New biofuel alternatives: integrating waste management and single cell oil production. Int. J. Mol. Sci 16(5): 9385-9405.

91. Li Q, Du W, Liu D (2008) Perspectives of microbial oils for biodiesel production, Appl. Microbiol. Biotechnol 80: 749-756

92. Patel A, Sindhu D K, Arora N, et al. (2015). Biodiesel production from non-edible lignocellulosic biomass of Cassiafistula L. fruit pulp using oleaginous yeast RhodosporidiumkratochvilovaeHIMPA1. Biores. Technol 197: 91-98.

93. Refaat AA (2010) Different techniques for the production of biodiesel from waste vegetable oil. Int J Environ Sci Tech 7 (1): 183-213.

94. Thanh LT, Okitsu K, Boi LV, Maeda Y (2012) Catalytic technologies for biodiesel fuel production and utilization of glycerol: a review. Catalysts 2: 191-222.

95. De Carvalho RNL (2009) Dilute acid and enzymatic hydrolysis of sugarcane bagasse for biogas production. University Press: Lisbon. p. 100 .

96. McCarty P L (1982) Anaerobic Digestion. Elsevier Biomedical Press: Amsterdam, New York, Oxford. 3-22.

97. Jingura RM, Kamusoko R (2017) Methods for determination of biomethane potential of feedstocks: a review.Biofuel Res J 14: 573-586.

98. Schlagermann P, Gottlicher G, Dillschneider R, et al. (2012) Composition of algal oil and its potential as biofuel. J Combust : 1-14.

99. Islam MA, Magnusson M, Brown RJ, et al. (2013) Microalgal species selection for biodiesel production based on fuel properties derived from fatty acid profiles. Energies 6: 5676-5702.

100. Veillette M, Giroir-Fendler A, Faucheux N, Heitz M (2017) Biodiesel from microalgae lipids: 45 from inorganic carbon to energy production. Biofuels 15: 1-28.

101. Jankowska E, Sahu AK, Oleskowicz-Popiel P (2017) Biogas from microalgae: review onmicroalgae's cultivation, harvesting and pretreatment for anaerobic digestion. Renew Sustain Energy Reviews 75:692-709. 
102. Jahirul MI, Rasul MG, Chowdhury AA, Ashwath N (2012) Biofuels production through biomass pyrolysis. Energies 5(12): 4952-5001.

103. Wankhade RD, Bhattacharya TK (2017) Pyrolysis oil an emerging alternate fuel for future (review). J Pharmacogn. Phytochem 6(6) 239-243.

104. Roy P, Dutta A (2013) A review of life cycle of ethanol produced from biosyngas. Bioethanol 1(1): 9-19.

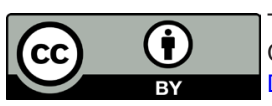

This work is licensed under Creative Commons Attribution 4.0 License

DOI: 10.19080/AJOP.2018.01.555553
105. Masuda TT (2006) Feedstock recycling and pyrolysis of waste plastics. John Wiley \& Sons: Chichester: 161-192.

106. Patel KD, Patel TM (2017) Performance and emission analysis of diesel engine using waste plastic pyrolysis oil and diesel blend: a review. IJSRD 4(12): 2321-2613.

\section{Your next submission with Juniper Publishers will reach you the below assets}

- Quality Editorial service

- Swift Peer Review

- Reprints availability

- E-prints Service

- Manuscript Podcast for convenient understanding

- Global attainment for your research

- Manuscript accessibility in different formats

( Pdf, E-pub, Full Text, Audio)

- Unceasing customer service

Track the below URL for one-step submission https://juniperpublishers.com/online-submission.php 